\title{
Efek suplementasi seng terhadap gejala yang berhubungan dengan diare akut ringan pada anak
}

\author{
Esther Boas \\ Puskesmas Kalianda Lampung Selatan \\ Email: Estherboas89@yahoo.co.id
}

\begin{abstract}
Diarrhea is still a serious problem and is one of the factors that led to infant and young children's deaths in developing countries, including Indonesia. Morbidity (Incidence Rate) diarrhea for all age groups in Lampung from year 2005 to 2012 are likely to rise, from 9.8 per 1000 population to 18.24 per 1000 population in 2012. It is known that zinc plays some important roles in regulation of intestinal fluid transport, maintainance of mucosal integrity, as well as improvement of immunity, gene expression, and oxidative stress. This study aimed to obtain the effect of zinc supplementation on symptoms associated with diarrhea on the seventh day of therapy in puskesmas (primary helath care) Kalianda, South Lampung. This was a randomized control trial study with a cross sectional design. Samples were children with mild acute diarrhea, divided into two groups: zinc group and without zinc group. Patients who showed no more acute diarrhea symptoms within seven days of treatment were determined as recovered. Data were presented in tabular form and analyzed by using the chi-square test. The results showed a total samples of 61 patients with acute mild diarrhea. The highest percentages were as follows: age 4 years old (19.6\%), male gender (54.1\%), and 2-day duration of diarrhea before admitted to Puskesmas Kalianda (44,26\%). The chi-square test showed a significant difference between the two groups $(P<0.001)$. Conclusion: Supplementation of zinc added to oralit in children with mild acute diarrhea can significantly reduce symptoms of mild acute diarrhea on the seventh day compared to oralit monotherapy.
\end{abstract}

Keywords: acute diarrhea, zinc, oralit

\begin{abstract}
Abstrak: Penyakit diare masih menjadi masalah yang serius dan merupakan salah satu faktor yang menyebabkan kematian bayi dan balita di negara berkembang termasuk Indonesia. Angka kesakitan (Incidence Rate) diare untuk semua kelompok usia di Provinsi Lampung dari tahun 2005-2012 cenderung meningkat, yaitu dari 9,8 per 1000 penduduk menjadi 18,24 per 1000 penduduk di tahun 2012. Seng diketahui membantu mengatur transpor cairan intestinal, menjaga integritas mukosa, meningkatkan imunitas, memperbaiki ekspresi gen dan stress oksidatif. Penelitian ini bertujuan untuk mengetahui efek pemberian suplemen seng terhadap penyembuhan dari gejala-gejala yang berhubungan dengan diare pada anak di hari ketujuh terapi di Puskesmas Kalianda, Lampung Selatan. Jenis penelitian ini ialah randomized control trial dengan desain potong lintang. Sampel penelitian ialah pasien anak dengan diare akut ringan yang dibagi menjadi dua kelompok: kelompok seng dan kelompok tanpa seng. Pasien yang menunjukkan hilangnya gejala diare akut dalam tujuh hari pengobatan dinyatakan sembuh. Data yang diperoleh dipresentasikan dalam bentuk tabel dan dianalisis dengan uji Chi-square. Hasil penelitian memperlihatkan terdapat 61 pasien anak sebagai sampel. Persentasi tertinggi diperoleh pada usia 4 tahun $(19,6 \%)$, jenis kelamin laki-laki $(54,1 \%)$, dan lama diare sebelum dibawa ke puskesmas ialah 2 hari (44,26\%). Hasil uji Chi-square memperlihatkan terdapat perbedaan bermakna antara kedua kelompok $(P<0,001)$. Simpulan: Pemberian suplementasi seng dan oralit pada anak dengan diare akut dapat menurunkan gejala diare akut ringan secara bermakna pada hari ketujuh dibanding pemberian oralit tunggal.
\end{abstract}

Kata kunci: diare akut, seng, oralit 
Penyakit diare masih menjadi masalah serius dan merupakan salah satu faktor penyebab kematian bayi dan balita di negara berkembang termasuk Indonesia. Angka kesakitan (Incidence Rate) diare untuk semua kelompok usia di Provinsi Lampung dari tahun 2005-2012 cenderung meningkat, yaitu dari 9,8 per 1000 penduduk menjadi 18,24 per 1000 penduduk tahun 2012. Diare menduduki peringkat ke-8 dalam 10 penyakit terbanyak di Provinsi Lampung dan mencakup $12 \%$ kematian anak balita berusia antara 1-5 tahun. ${ }^{1}$ Hal-hal di atas membuat diare menjadi salah satu masalah kesehatan penting di Provinsi Lampung.

WHO melaporkan bahwa sekitar 17,3\% dari penduduk dunia berisiko kekurangan asupan elemen seng. ${ }^{2}$ Wilayah Provinsi Lampung higga saat ini belum memiliki laporan angka kecukupan asupan seng. Diare akut pada anak berhubungan dengan kekurangan elemen ini. $^{3}$ Seng diketahui membantu mengatur transpor cairan intestinal, menjaga integritas mukosa, meningkatkan imunitas, serta memperbaiki ekspresi gen dan stres oksidatif yang mana hal tersebut dapat membantu kekambuhan penyakit diare pada anak dua sampai tiga bulan sesudah pemberiannya. ${ }^{4}$

Penelitian ini bertujuan melihat efek pemberian suplemen seng terhadap penyembuhan dari gejala-gejala yang berhubungan dengan diare di Puskesmas Kalianda, Lampung Selatan.

\section{METODE PENELITIAN}

Penelitian ini merupakan penelitian randomized control trial. Penelitian ini melihat efek dari pemberian suplemen seng pada anak dibandingkan dengan plasebo. Penelitian ini dilakukan di Puskesmas Kalianda, Lampung Selatan dari Desember 2014 hingga Febuari 2015.

Kriteria inklusi berupa anak dengan gejala buang air besar lebih dari 3 kali dalam 24 jam dengan konsistensi lunak atau cair. Kriteria eksklusi berupa diare kronik, diare sedang dan berat, pasien dengan alergi seng dan pasien dengan kegawatan karena diare.
Sampel didapatkan secara consecutive sampling untuk pasien yang datang ke puskesmas Kalianda, Lampung Selatan yang memenuhi kriteria inklusi eksklusi. Kelompok pertama diberi seng $10 \mathrm{mg}$ dispersible sebanyak satu kali sehari disertai pemberian oralit dan kelompok kedua hanya diberikan oralit.

Data yang diperoleh dipresentasikan dalam bentuk tabel dan diuji dengan menggunakan Chi-square. Pasien yang menunjukkan hilangnya gejala diare akut dalam tujuh hari pengobatan dikategorikan sembuh dan pasien dengan gejala diare akut dalam tujuh hari pengobatan dikategorikan belum sembuh.

\section{HASIL PENELITIAN}

Sebanyak total 61 pasien yang memenuhi kriteria inklusi dan eksklusi ikut dalam penelitian ini. Persentase tertinggi dijumpai pada usia 4 tahun sebanyak 12 anak (19,6\%); jenis kelamin laki-laki sebanyak 33 anak $(54,1 \%)$; pendidikan terakhir orang tua SD sebanyak 30 orang $(49,2 \%)$; pekerjaan orang tua petani dan karyawan masing-masing sebanyak 16 orang $(26,2 \%)$; serta lama diare sebelum dibawa ke puskesmas ialah 2 hari sebanyak 27 anak (44,26\%) (Tabel 1).

Berdasarkan data yang dikumpulkan dari 61 pasien, terdapat perbedaan yang signifikan antara kelompok diberi seng dan tidak diberi seng $(\mathrm{p}<0,001)$ (Tabel 2).

\section{BAHASAN}

Penelitian ini bertujuan melihat efek pemberian suplementasi seng dan oralit untuk penderita diare akut pada anak dibanding pemberian oralit sebagai penatalaksanaan tunggal. Hasil penelitian menunjukkan efikasi pemberian seng yang cukup baik dimana semua gejala diare akut ringan menghilang pada hari ketujuh dibanding pemberian oralit tunggal dimana pada hari ketujuh masih terdapat 19 subjek dengan gejala diare akut ringan.

Seng merupakan mikronutrien penting bagi tubuh manusia. Seng yang berfungsi 
Tabel 1. Karakteristik pasien

\begin{tabular}{lccc}
\hline \multicolumn{1}{c}{ Variabel } & \multicolumn{2}{c}{ Pemberian seng } & \\
& Diberi & $\begin{array}{c}\text { Tidak } \\
\text { diberi }\end{array}$ & Total \\
\hline Jenis kelamin & & & \\
$\quad$ laki - laki & 17 & 16 & 33 \\
perempuan & 14 & 14 & 28 \\
Usia (tahun) & & & \\
1-3 & 10 & 10 & 20 \\
4-6 & 13 & 12 & 25 \\
7-9 & 7 & 7 & 14 \\
10-12 & 1 & 1 & 2 \\
Pendidikan terakhir & & & \\
ibu & & & \\
SD & 14 & 16 & 30 \\
SMP & 6 & 6 & 12 \\
SMA & 8 & 5 & 13 \\
D3 & 3 & 3 & 6 \\
Pekerjaan Ibu & & & \\
Petani & 9 & 7 & 16 \\
Wiraswasta & 2 & 3 & 5 \\
Karyawan & 10 & 6 & 16 \\
Buruh & 4 & 6 & 10 \\
IRT & 6 & 8 & 14 \\
Lama diare (hari) & & & \\
1 & 3 & 6 & 9 \\
2 & 18 & 9 & 27 \\
3 & 9 & 13 & 22 \\
4 & 1 & 2 & 3 \\
\hline
\end{tabular}

Tabel 2. Perbandingan gejala diare pada kelompok diberi seng dan tidak

\begin{tabular}{lccc}
\hline \multirow{2}{*}{ Pemberian } & \multicolumn{2}{c}{ Gejala diare } \\
setelah 7 hari & Total \\
\cline { 2 - 3 } & Menghilang & $\begin{array}{c}\text { Masih } \\
\text { ada }\end{array}$ & \\
\hline Diberi & 31 & 0 & 31 \\
Tidak & 11 & 19 & 30 \\
Total & 42 & 19 & 61 \\
\hline
\end{tabular}

dalam regenerasi sel juga membantu mencegah oksidasi sel. ${ }^{5}$

Seng berfungsi penting pada tumbuh kembang anak akan tetapi masih menjadi masalah defisiensi di negara berkembang di dunia termasuk Indonesia. ${ }^{6,7}$ Selain berhubungan dengan tumbuh kembang anak, seng juga berfungsi dalam kekebalan tubuh sebagai second messenger dalam transduksi sinyal, imunitas sel, dan imunitas nutrisional. ${ }^{8}$ Sampai saat ini Lampung Selatan masih belum memiliki data akurat mengenai kecukupan asupan mikronutrien seng pada penduduk di daerahnya.

Hubungan seng dengan diare masih belum jelas. Lokasi kerja seng kemungkinan besar berada di usus halus dengan menghambat sekresi cairan yang diinduksi oleh adenosine 3',5'- cyclic monophosphate (cAMP). Seng menghambat sekresi klorida yang diinduksi cAMP dengan menghambat saluran kalium. Seng juga merangsang sekresi kalsium intrasel dan mengatur transpor ion. Mekanisme ini kemudian menghambat pelepasan cairan di saluran cerna. Seng juga menghambat toksin yang diinduksi oleh kolera tetapi tidak menghambat toksin dari Escherichia coli yang tahan terhadap panas. ${ }^{8}$

Mencegah lebih baik daripada mengobati. Salah satu masalah dalam suplementasi seng pada masyarakat ialah efektifitas dari biaya. Patel $^{9}$ menyatakan bahwa perlu tambahan 520 rupee atau sekitar \$11 untuk pemberian suplementasi seng pada seorang pasien diare akut. Anak dengan defisiensi seng memerlukan asupan seng antara $2-4 \mathrm{mg} / \mathrm{kg}$ berat badan (BB) dibanding kebutuhan $0,17 \mathrm{mg} / \mathrm{kg}$ BB untuk usia 1-3 tahun pada anak normal. ${ }^{10}$ Permasalahan ini mungkin dapat diatasi dengan fortifikasi lahan pertanian/ perkebunan dan pemilihan asupan makanan yang sesuai dengan tumbuh kembang anak. $^{11}$

\section{SIMPULAN}

Berdasarkan hasil penelitian dan bahasan dapat disimpulkan bahwa pemberian suplementasi seng dan oralit pada anak dengan diare akut dapat menurunkan gejala diare akut ringan secara bermakna pada hari ketujuh dibanding pemberian oralit tunggal.

\section{DAFTAR PUSTAKA}

1. Dinas Kesehatan Provinsi Lampung. Lampung: Profil Kesehatan Provinsi 
Lampung, 2012.

2. Wessells KR, Brown KH. Estimating the global prevalence of zinc deficiency: Results based on zinc availability in national food supplies and the prevalence of stunting. PLoS ONE 2012;7:11: e50568. doi:10.1371/ journal.pone. 0050568

3. Poerwati E, Hegar B. Zinc supplementation in children with acute diarrhea of invasive bacterial and non-bacterial infection. Indonesian Journal of Gastroenterology Hepatology Digestivus Endoscopy. 2012;13:70.

4. Canani B, Roberto, Buccigrossi, Vittoria, Passariello, Annalisa. Mechanisms of action of zinc in acute diarrhea. Curr Opin Gastroenerol. 2011;27(1):8-12.

5. Kloubert V, Rink L. Zinc as a micronutrient and its preventive role of oxidative damage in cells. Food Funct. 2015;6(10):3195-204.

6. Dijkhuizen MA, Wieringa FT, West CE, Martuti S. Effects of iron and zinc supplementation in Indonesian infants on micronutrient status and growth. $\mathrm{J}$ Nutr. 2001;131(11):2860-5.

7. Gibson RS. Zinc: the missing link in combating micronutrient malnutrition in developing countries. Proceedings of the Nutrition Society. 2006 Feb 1;65(1):51-60.

8. Lukacik M, Thomas RL, Aranda JV. A meta-analysis of the effects of oral zinc in the treatment of acute and persistent diarrhea. Pediatrics. 2008;121(2):326-36.

9. Patel AB, Badhoniya N, Dibley MJ. Zinc and copper supplementation are not cost-effective interventions in the treatment of acute diarrhea. Journal of Clinical Epidemiology. 2013;66(1):5261.

10. Roohani N, Hurrell R, Kelishadi R, Schulin R. Zinc and its importance for human health: An integrative review. J Res Med Sci. 2013;18:144-57.

11. Lönnerdal B. Genetically modified plants for improved trace element nutrition. J Nutr. 2003;133:1490S-3S. 